\title{
os escravos que saint-hilaire viu ${ }^{1}$
}

Flávio Rabelo Versiani

Departamento de Economia, Universidade de Brasília

\section{Introdução}

Relatos de viajantes que percorreram o Brasil, especialmente no século XIX, têm sido fontes amplamente utilizadas para o estudo da vida econômica e social do País naquele período. Os trabalhos clássicos de Gilberto Freyre, Sérgio Buarque de Holanda e Caio Prado Jr., por exemplo, valeram-se em larga medida dessas fontes. ${ }^{2}$

Em particular, o estudo das características do escravismo brasileiro tem sido muito influenciado por tais relatos. A visão de uma escravidão relativamente benigna no Brasil - origem de tanta polêmica na literatura - foi com freqüência defendida com o apoio de citações extraídas da obra de observadores estrangeiros da época. Com efeito, nos livros de viajantes como Henry Koster, George Gardner, John Luccock, John Mawe, Johann Emanuel Pohl e Auguste de Saint-Hilaire, entre outros, não é raro encontrar menções a um tratamento aparentemente pouco rigoroso, ou mesmo benévolo, dispensado à mão-de-obra cativa no Brasil. Por outro lado, a fidedignidade desses testemunhos foi posta em dúvida por oponentes daquela visão, desde o século XIX. Não faltou quem considerasse os Viajantes "verdadeiros agentes do governo

\footnotetext{
Este artigo decorrede pesquisa apoiada pelo CNPq, a qual contou com a competente colaboração, como assistente de pesquisa, de Fábio Souza de Oliveira. O texto se beneficiou de comentários dos participantes de seminários em que versões anteriores do trabalho foram apresentadas, sendo de se destacar os da Profa M.Teresa $R$. Oliveira. Mas, é claro que só o Autor deve ser responsabilizado pelo produto final.

V. especialmente Freyre, 1981[1933], 1961[1936]; Holanda, 1989[1936]; Podo Jr., $1981[1942]$.
} 
brasileiro", prestando-se a veicular uma tese que teria sua origem na propaganda antiabolicionista governamental, interessada em difundir um quadro róseo da situação dos escravos. ${ }^{3}$

Nesse contexto, será útil procurar examinar de forma mais sistemática o que disseram os viajantes do século XIX sobre o escravismo brasileiro, indo além de meras citações pinçadas a propósito. Até que ponto se pode extrair desses relatos um quadro coerente, que traga subsídios efetivos ao entendimento das relações entre senhores e escravos? Que tipo de generalização pode ser sugerida por esse mosaico de observações individuais, feitas em circunstâncias bastante variadas?

O presente trabalho pretende trazer uma contribuição em tal sentido, examinando os depoimentos, com relação à escravidão, de um dos mais importantes e freqüentemente citados entre aqueles viajantes: o naturalista francês Saint-Hilaire, que percorreu extensamente o Brasil entre 1816 e 1822. O exame dos relatos de Saint-Hilaire será feito tomando como referência algumas hipóteses e conclusões da literatura econômica sobre o escravismo.

A próxima seção expõe brevemente tópicos da análise econômica da escravidão relevantes para a discussão que se seguirá. Trata-se, depois, da postura de Saint-Hilaire diante da escravidão e de sua visão geral quanto às relações entre escravos e homens livres no Brasil. As seções subseqüentes examinam as observações do Viajante sobre o escravismo na mineração, na cultura da cana-de-açúcar e em outras lavouras, e na criação de gado. Em seguida discutem-se alguns aspectos específicos do seu testemunho sobre as relações escravistas no Brasil. Uma seção final reúne as conclusões do artigo.

\section{Mão-de-obra escrava: produtividade e formas de utilização}

Cabe referir aqui duas proposições desenvolvidas na literatura sobre economia da escravidão nas últimas décadas, e que se mostram relevantes para o entendimento de questões relacionadas com o desenvolvimento da escravidão no Brasil. ${ }^{4}$ Primeiro, a idéia da produtividade diferente

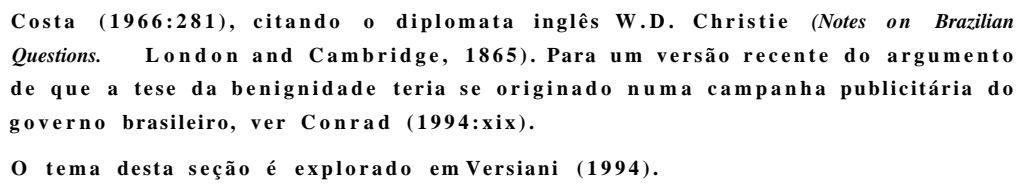


dos dois tipos de mão-de-obra; segundo, a distinção entre atividades ou tarefas que exigem apenas força bruta, de um lado, e aquelas que requerem do trabalhador habilidade ou esmero, do outro.

A proposição de que a mão-de-obra escrava é, dentro de certos limites e mantidos os demais fatores constantes, mais produtiva que a livre, aparece de diversas formas na moderna literatura sobre escravismo. A superioridade do trabalho escravo tem sido associada a causas variadas, desde economias de escala obtidas na organização do trabalho agrícola em equipes de escravos (Fogel \& Engerman, 1974) à redução dos custos de transação derivados da rotatividade da mão-de-obra livre (Hanes, 1996). Um argumento que parece ter grande generalidade decorre da idéia de que o que distingue fundamentalmente o trabalho escravo do trabalho livre é o fato de que, enquanto, no segundo caso, o tempo de trabalho é decidido pelo próprio trabalhador, a partir de uma avaliação dos custos e benefícios de uma hora de trabalho adicional, na escravidão essa decisão cabe ao proprietário; e, nesse caso, o tempo de trabalho pode ser aproximado do máximo biologicamente suportável, mediante o uso, efetivo ou potencial, da coerção física. Ao contrário, o dia de trabalho assalariado tem uma duração tipicamente inferior a esse máximo. Neste sentido, dado um mesmo custo do dia de trabalho (dado, para o escravo, pelo custo de sua aquisição, descontado no tempo, mais o custo de sua manutenção e da coerção a ele aplicada; e,para o trabalho livre, por seu salário), o trabalho escravo é mais produtivo. A decisão "racional" sobre o uso de uma ou de outra forma de trabalho basear-se-á, então, na comparação de seus custos, levando em conta essa produtividade potencial.

O segundo desses pontos acima foi explorado por Fenoaltea (1984), que distinguiu dois tipos polares de atividades produtivas. De um lado, as atividades "intensivas em esforço", que requerem basicamente força, podendo a avaliação do desempenho do executante ser feita de forma quantitativa. São normalmente associadas a uma determinada forma de organização do trabalho, que facilite seu acompanhamento e fiscalização e a aferição do resultado. O remador de uma galera, na Antigüidade, trabalhando sob os olhos de um patrão, exercia uma tarefa desse tipo; cavar buracos, carregar pedras, capinar uma roça são basicamente tarefas intensivas em esforço. No outro extremo, tarefas "intensivas em

Argumentos nessa linha foram desenvolvidos por vários autores; verparticularmente Domar (1970) e Barzel (1977). 
habilidade" são aquelas em que a qualidade da execução é fundamental; elas não podem ser avaliadas apenas pela quantidade do produto. A atividade de quem conserta um mecanismo complexo ou delicado é um exemplo típico. Evidentemente, entre os dois extremos há uma gama contínua de misturas de força e habilidade.

Juntando agora os dois argumentos, é evidente que a idéia da produtividade superior da mão-de-obra escrava só terá aplicabilidade nos casos em que a coerção for viável; e ela só será viável em atividades intensivas em esforço. É difícil, ou impossível, garantir a execução de uma atividade intensiva em habilidade mediante castigos ou ameaças; nesse caso, é imprescindível certo grau de cooperação por parte do trabalhador. A falta de qualidade não é, em geral, facilmente aferível. Será necessário angariar tal cooperação; e a forma mais adequada de fazer isso será por meio de incentivos ou recompensas - em suma, de alguma forma de salário.

Um corolário dessas hipóteses é que o trabalho escravo é relativamente mais eficiente para a execução de tarefas intensivas em esforço do que intensivas em habilidade. Neste sentido, a escravidão seria primariamente usada como forma de suprimento de mão-de-obra ali onde as atividades produtivas são caracterizadas pela predominância de tarefas intensivas em esforço - como na agricultura organizada sob o sistema de plantation. Só secundariamente, de forma derivada, adviria o uso de escravos em outros tipos de atividade. Um outro corolário é que a coerção estará basicamente associada a atividades em que predominem tarefas intensivas em esforço. Na agricultura de plantation, a organização do trabalho em equipes pode ser vista, assim, como uma forma de administrar a coerção mais eficientemente. Simetricamente, onde prevalecem tarefas intensivas em habilidade (como na escravidão doméstica) a coerção seria menos comum, e a ocorrência de incentivos positivos (recompensas, inclusive alforrias) mais freqüente.'

Tendo em mente esse arcabouço conceituai, passa-se agora a examinar as referências ao escravismo-brasileiro encontrados nos relatos de SaintHilaire.

\footnotetext{
Para um tratamento desse ponto sob o ângulo da teoria do agente, ver Kahn (1992).

Fenoaltea (1984). Para ilustraçóes desses pontos com referência ao caso brasileiro, veja-se Versiani (1994).
} 


\section{Saint-Hilaire e a escravidão}

Auguste de Saint-Hilaire veio ao Brasil em 1816 com o Duque de Luxemburgo, embaixador francês, e aqui permaneceu até 1822. Naqueles seis anos percorreu cerca de 15 mil quilômetros, em cinco viagens, tendo a cidade do Rio de Janeiro como base.

Sua primeira viagem, uma excursão de cerca de um mês, levou-o até uma fazenda do vale do Paraíba. Na segunda, de quinze meses, percorreu extensamente a província de Minas Gerais, em especial a zona de mineração - inclusive o Distrito Diamantino - passando ainda pelo vale dojequitinhonha e alcançando a atual Montes Claros, no norte da Província. A terceira viagem, de aproximadamente três meses, levouo até o rio Doce, pelo litoral do Rio de Janeiro e Espírito Santo. Na quarta viagem, a mais longa, que durou aproximadamente dois anos e meio, percorreu novamente Minas Gerais, agora ao sul da Zona Metalúrgica, no sentido do vale do Rio Grande, indo até Araxá; passando à província de Goiás, foi até a cidade de Goiás, voltou ao sul da Província, atravessou o atual Triângulo Mineiro e entrou em São Paulo, próximo a Franca; passando por Mojimirim e Campinas chegou à capital da Província, de onde desceu, por Itapeva e Itararé, para o hoje Estado do Paraná; por Curitiba e Paranaguá atingiu a província de Santa Catarina e, pela zona litorânea, chegou ao Rio Grande do Sul, até Porto Alegre e Rio Grande; passou ao hoje Uruguai, retornou ao Rio Grande atravessando a Província até o norte, voltando a Porto Alegre, de onde embarcou de volta ao Rio. O quinto e último percurso, de cerca de quatro meses, levou-o novamente a Minas, até São João del Rei, e daí ao sul da Província, onde entrou em São Paulo, perto de Guaratinguetá, percorrendo então o vale do Paraíba até a capital da Província e, em sentido contrário, de volta ao Rio. No todo, teve cerca de quatro anos e meio de viagens pelo País, dos quais quase dois anos em Minas Gerais.

Saint-Hilaire dedicou-se primordialmente ao estudo da flora brasileira, tendo publicado uma obra botânica de enorme importância, com descrição de centenas de novas espécies. Seus relatos de viagem revelam não só o naturalista minucioso, mas também um observador arguto da realidade social que tinha sob seus olhos. ${ }^{8}$

\footnotetext{
"Os relatos de viagem de Sain-Hilaire foram publicados na França entre 1830 e 1887. Aqui me referirei à tradução, em nove volumes, editada na década de setenta (Saint-Hilaire, 1974a；1974b;1974c;1975a;1975b;1975c;1975d;1976;1978). No que se segue, esses volumes serão citados de forma abreviada por DD (Viagem
} 
Em suas atitudes com relação à escravidão, nota-se, além das idéias de inferioridade racial de negros e mulatos, próprias da época, certo conflito entre a condenação moral da instituição servil, várias vezes reafirmada, e aquilo que observava e anotava, com minúcia e espírito científico, sobre as condições de vida e de trabalho dos escravos.

O preconceito racial transparece já na narrativa de sua primeira incursão ao Interior, do mês passado numa fazenda do vale do Paraíba. No retorno ao Rio, seu hospedeiro lhe dá mantimentos para a viagem e um escravo como guia. "Não sabendo ainda o que são os escravos, e principalmente os de sangue mestiço", deixou tudo a cargo do guia,"o bom Antônio" - o qual lhe furtou os mantimentos (MG, p. 34). Inúmeras observações desse teor racista encontram-se em suas narrativas. Em particular, ele usualmente atribui à predisposição indolente e preguiçosa de negros e mestiços as dificuldades que encontra em engajar mão-de-obra que o auxiliasse em suas viagens.

Mas, os preconceitos do naturalista - e a rígida moralidade que o fazia julgar obscenas e lúbricas as festas e danças dos negros, e atribuirlhes outros vícios morais - não o impediam de ter uma atitude compassiva para com os escravos, e ver superioridades físicas na raça: "Não existe um só viajante que não tenha tido ocasião de observar que, para todos os exercícios em que são necessárias medida e precisão, os africanos são geralmente superiores aos povos da Europa. Seus cantos e danças são, sem dúvida, bárbaros; mas sabem executá-los com uma perfeição geralmente desconhecida aos franceses de classe inferior." (MG, p. 18).

O conflito entre suas idéias anteriores sobre a escravidão e o que encontrou no Brasil é bem ilustrado por um incidente de sua primeira viagem a Minas Gerais, que parece ter sido marcante para ele: trata-se de uma passagem várias vezes referida em seus relatos posteriores. Não distante do então rancho de juiz de Fora, o Viajante, recolhendo plantas

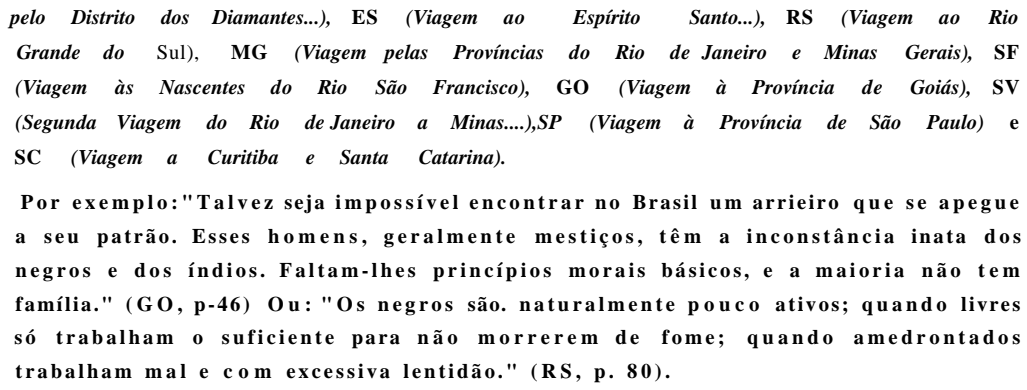


próximo à estrada, deu com um negro que, à beira de uma plantação de milho, comia próximo de sua choça, e gentilmente lhe ofereceu uma cabaça de tatu com angu. Indagado de suas condições de vida, o preto as avalia com otimismo, rebatendo as sugestões em contrário do Naturalista. Não se aborrece vivendo só no meio do mato? Não, pois sua casa não é distante, e ele tem seu trabalho. Não sente saudade da terra, da costa da África? Não, acha melhor aqui, veio menino e se acostumou. Mas, é escravo, não pode fazer o que quer. Sim, mas o seu senhor é bom, dá muito de comer, bateu-o poucas vezes, deixa que ele trabalhe sua roça nos domingos, com o que arranja algum dinheiro. Vai casar com uma conterrânea que sua senhora acaba de comprar; o senhor lhe havia oferecido uma crioula, mas ele não a quis, as crioulas desprezam os negros da costa. (MG, p. 53).

Esse diálogo perturbou os conceitos anteriores de Saint-Hilaire, mostrando-lhe que "os negros não são sempre tão infelizes como se diz" (ibid.). Diversas vezes depois, ele voltou a perguntar a escravos africanos se não sentiam saudades de sua terra, e recebeu sempre resposta negativa: lá há muita guerra, aqui é melhor; se voltássemos, seríamos vendidos de novo. O viajante racionalizava isso também a partir da imprevidência natural da raça, no seu modo de ver: como os escravos pensam pouco no futuro, o presente, sendo suportável, é o que lhes parece suficiente. "A escravidão não é para eles o que seria para nós." (MG, p. 54).

Mas, Saint-Hilaire justificou também essa atitude dos cativos a partir do fato de que suas condições de vida eram muitas vezes aceitáveis, ou boas:

"No estado atual das coisas, devemos, para ser justos, fazer concessões aos partidários da escravidão. $O$ negro que cai nas mãos de um senhor bom e sinceramente cristão é, devemos confessá-lo, mais feliz do que a maioria dos camponeses de certas províncias da França; trabalha muito menos; não tem as mesmas inquietações; a fome e a miséria não o ameaçam constantemente; vivendo num clima quente, tem poucas necessidades, e aquilo de que carece o senhor the dá [...]." (MG, p. 54)

Mas, logo em seguida, restringe a amplitude desse juízo favorável sobre a escravidão brasileira, advertindo: "Mas não é menos verdade que o escravo corre maiores perigos de miséria que de felicidade, por que os senhores desumanos são mais numerosos do que os bons." (ibid.). 
Também o impressionou um fato ocorrido na região de Minas Novas: um escravo, com uma coleira de ferro ao pescoço, lançou-se a seus pés pedindo sua intercessão para livrá-lo do terrível castigo."Algumas palavras bastaram para pôr termo à punição desse infeliz", demonstrando "quanto são brandos os costumes dos habitantes do Brasil [...]". (MG, p. 283)

Em relatos subseqüentes - convém lembrar que Saint-Hilaire só transformou suas anotações em livros já na França, anos depois de voltar do Brasil, e ao longo de quase três décadas - o Viajante reafirmou mais de uma vez, e agora sem qualificações ou restrições, o argumento de que os escravos tinham, nas regiões que percorrera, e especialmente em Minas Gerais, um tratamento relativamente brando. Nessa generalização maior que dá a tal argumento, ele pode ter sido influenciado por outras narrativas de viajantes europeus no Brasil que apareceram depois de seu retorno à França, as quais lia cuidadosamente, cotejando-as com suas notas. Assim, na Viagem às Nascentes do São Francisco (cuja primeira edição francesa saiu em 1847), escreveu:

"Apresso-me a esclarecer que na Província de Minas Gerais [os negros] me pareceram tratados com bastante doçura, e é certo que mesmo no Pão de Janeiro o tratamento que recebem é bem melhor do que nos Estados do Sul da Confederação Americana. O consciencioso escritor que acabei de citar [Ferdinand Denis],bem como Spix e Martius, Gardner e mesmo o Conde de Suzannet, que mostrou tão pouca benevolência para com os brasileiros, são acordes em reconhecer que estes são geralmente muito indulgentes em seu trato com os escravos." (SF, p. 70)

E prossegue com uma extensa citação de Gardner, em que esse afirma ter encontrado, em sua longa estada no Brasil, poucos casos de "pura e simples crueldade"para com os escravos, os quais, na maioria das fazendas, "são bem tratados e parecem bastante felizes" (ibid.). Esse autor tinha feito entre escravos africanos indagações similares às de Saint-Hilaire, com resultados análogos: raramente os cativos mostravam qualquer ressentimento por terem sido trazidos da África para o Brasil, ou desejo de retornar ao país de origem."

10 O livro de George Gardner, Travels in the Interior of Brazil, fora publicado em Londres em 1846. Essa data deixa claro, aliás, que Saint-Hilaire acompanava com atenção o que se publicava na Europa sobre o Brasil, pois seu livro sobre a viagem às nascentes do São Francisco, no qual cita Gardner, apareceu já no ano seguinte. 
Mais tarde, em seu Viagem a Curitiba e Província de Santa Catarina (editado na França em 1851), Saint-Hilaire foi anda mais enfático:

"Todo mundo sabe, de resto, que os brasileiros tratam geralmente os escravos com grande brandura. A esse propósito podem ser consultados os trabalhos de Gardner ("Traveis") e mais recentemente os de Blumenau ("Süd Brazilien"); finalmente, o que eu próprio escrevi em minha Viagem às Nascentes do Rio São Francisco." (SC, p. 173 n. 365)

Ainda que as observações de outros viajantes possam ter contribuído para solidificar a posição de Saint-Hilaire a esse respeito, seria inteiramente alheia a sua personalidade de cientista, de pesquisador cuidadoso e infatigável, a atitude de simplesmente reproduzir opiniões de terceiros. É evidente que a idéia de uma escravidão "suave", da prevalência de uma postura benigna dos senhores em relação à mão-de-obra cativa que possuíssem, coincidia, no geral, com o que ele próprio vira, em seus seis anos de andanças pelo centro-sul do Brasil.

Torna-se, assim, relevante perguntar: quais foram os escravos que Saint-Hilaire viu? As próximas seções deste artigo procuram reunir elementos para uma resposta a essa questão.

\section{Escravos e homens livres}

Uma primeira observação refere-se às repetidas menções de SaintHilaire ao fato de que escravos e pessoas livres às vezes se misturavam com naturalidade, em lugares públicos ou mesmo em atividades de produção. Isso, é claro, contrapunha-se ao modelo convencional de escravidão; e o viajante se refere ao fato com certa surpresa (e às vezes com mal disfarçado desgosto).

Escravos conviviam com homens livres nas vendas de beira de estrada. Ainda próximo ao Rio de Janeiro, em sua primeira viagem a Minas, "a cada momento nossos ouvidos eram chocados pelo ruído confuso que faziam nas vendas os escravos confundidos aos homens livres de classe inferior." (MG, p. 36). E o moralista condena severamente o grande consumo de cachaça nessas vendas, e outros males que aí se praticavam:

"É lá que os escravos passam uma parte dos momentos de liberdade que se lhes concedem e dos que podem furtar a seus senhores; é para lá que levam o produto de seus roubos, dos quais os proprietários das 
vendas não foram talvez os menores cúmplices; é aí que eles acabam de se corromper, comunicando-se reciprocamente seus vícios, e que esquecem, na embriaguez, a escravidão e suas misérias." (MG, p. 40)

A menção a isso se repete mais de uma vez, em livros posteriores. Por exemplo: "A cada momento, passávamos à frente de alguma venda apinhada de escravos de envolta com homens livres." (SV,p. 15). (Ver também DD, p. 138, onde o Autor insiste na idéia de vendas como locais de receptação de roubos e bebedeiras de escravos, que aí "prolongam suas estranhas palestras noite adentro").

Também a religião trazia os negros parajunto dos brancos. Para assistir missa, "as mulheres, sem distinção de classe, colocam-se ao meio da igreja agachadas ou de joelhos" - embora os negros "e a gente da classe baixa" ficasse à porta (MG, p. 63). Numa fazenda de Borda do Campo, em Minas, o viajante foi encontrar o proprietário, um padre, fazendo as orações da tarde "em meio a uma trintena de pessoas, na maioria negros e negras." (MG, p. 60)

No trabalho agrícola, Saint-Hilaire notou convivência próxima de escravos e senhores em particular nas fazendas da Zona da Mata, em Minas, voltadas principalmente à criação de gado, como atividade lucrativa, e a culturas de auto-consumo. "[Na comarca de São João del Rei] os habitantes dos campos aplicam-se mais à agricultura. Trabalham com seus negros e passam a vida nas plantações, no meio dos animais, e seus costumes tomam, necessariamente, algo da rusticidade das ocupações." (SV, p. 37). Claramente essa convivência não lhe parecia muito recomendável; atribuiu a ela o fato de que os habitantes da Mata lhe parecessem menos cultivados e corteses do que os da Zona Metalúrgica, "que apenas vigiam os escravos, nada trabalham e têm mais ocasiões de conversar e pensar." (SV, p. 37-38). Ele julgou essa idéia suficientemente importante para repeti-la, quase com as mesmas palavras, em relato posterior (SF, p. 54-55). Viajando mais tarde por São Paulo, na região de Franca, pernoitou na casa de um fazendeiro originário da Zona da Mata, e se espantou ao ver como tudo na fazenda era parecido com as propriedades dessa região de Minas - inclusive o convívio próximo de brancos e negros. E escreveu, com algum sarcasmo:

"Na manhã seguinte, [...] os filhos do dono começaram a ordenhar [as vacas], misturados com as negras. O pátio era muito amplo e cercado por grossos mourões, como os de todas as fazendas da Comarca de São João del Rei. Em resumo, eu encontrei na casa de 
meu hospedeiro todos os hábitos dessa comarca." (SP, p. 95)

Os brancos não só bebiam, rezavam e trabalhavam junto dos escravos, mas às vezes dançavam com eles, e como eles. Em Goiás, numa festa de São João, o viajante presenciou um batuque, "uma dança obscena que os brasileiros aprenderam com os africanos". Era dançada só por homens - "e quase todos eram brancos", notou ele, em evidente reprovação. O que o fez concluir, mal-humorado:

"Os brasileiros devem, sem dúvida, alguma coisa a seus escravos, aos quais se misturam tão freqüentemente, e que talvez lhes tenham ensinado o sistema de agricultura que adotam e a maneira de extrair o ouro dos córregos. Além do mais, foram os seus mestres de dança." (GO,p. 47).

Ainda mais reprovável lhe pareceu o que presenciou perto de Vila do Fanado (Minas Novas), em Minas Gerais: concubinato e promiscuidade:

"Um colono nos arredores de S. João, em cuja casa me hospedei, tinha por escrava uma mulata que, sem ser casada, se tornara mãe de vários filhos. Um deles tinha por pai o próprio senhor; os demais pertenciam a vários pais e eram escravos do senhor. Toda essa gente vivia em promiscuidade, e costumes tais são tão generalizados que não espantam a ninguém." (MG, p. 203).

Mas, em alguns casos, o Viajante viu de forma positiva a proximidade entre senhores e escravos, na atividade produtiva. Se critica a recusa ao trabalho braçal por parte do homem branco, que vê como atitude predominante nas regiões onde predominava a mão-de-obra escrava (como na Zona Metalúrgica de Minas), considera positivo que alguns donos de escravos "não se envergonhem de trabalhar", e o façam lado a lado com seus cativos. Foi o que notou no Rio Grande do Sul, perto de Santa Maria:

"Todos os proprietários cultivam a terra, ao mesmo tempo que se dedicam à criação de gado. O dono da casa e seus filhos cuidam do gado e os negros tratam da plantação [referindo-se a seu hospedeiro]; nesta região, ninguém se envergonha de trabalhar. Os proprietários menos ricos possuem vacas de leite e cultivam a terra por suas próprias mãos." (RS,p. 179). 
Sem dúvida, as várias constatações de "mistura" entre os escravos e seus donos, em diferentes situações, contribuíram para compor o quadro mental que o Viajante formou do escravismo brasileiro. Mesmo que em muitos casos lhe desagradassem essas intimidades excessivas entre brancos e negros, o fato é que elas não se encaixavam bem na imagem de uma escravidão sempre marcada pela crueldade e pela violência. A aproximação entre senhores e escravos, ainda que vista como censurável, seria também um outro sinal da benignidade daqueles no trato de seus cativos.

\section{Escravos na mineração}

Foi nos trabalhos de mineração que Saint-Hilaire pôde primeiro observar, mais de perto, escravos entregues a uma atividade produtiva. Menos de vinte dias depois de deixar o Rio de Janeiro, em sua segunda viagem, chegava a Vila Rica; na região circunvizinha teve oportunidade de visitar várias lavras de ouro, especialmente nas cercanias de Itabira. No final do ano seguinte, passou cerca de um mês no Tijuco, onde percorreu vários "serviços" da Intendência dos Diamantes.

$\mathrm{Na}$ mineração do ouro, especialmente nas maiores explorações, a mão-de-obra escrava era usada com exclusividade; os homens livres só se dedicavam a fiscalizar o trabalho dos cativos. Os métodos de exploração pareceram ao Viajante muito ineficientes; a não ser o sistema de captação e condução de água para lavagem do minério, em que mostravam competência; "a arte de explorar minas não é entre os mineiros mais que uma rotina imperfeita e cega." (MG,p. 110). A operação inicial era o trabalho braçal, pesado, de extração do material aurífero nas minas de galeria ou de céu aberto (no caso da mineração "de morro"), ou o recolhimento do cascalho contendo o metal, no leito dos rios ou em outros locais (no caso da mineração "de cascalho"). Em qualquer caso, vinha em seguida o procedimento básico da extração do metal precioso: a lavagem ("único processo de que se servem os brasileiros para separar o ouro das matérias com que vem misturado, quaisquer que elas sejam.") (MG, p. 112). Consistia, em essência, de sucessivas passagens de água pela mistura aurífera, visando separar as partes de menor tamanho e nessas isolar, por gravidade, as partículas do metal. Estas ficavam depositadas no fundo dos recipientes e condutos usados no processo, ou eram retidas por couros de boi ou panos felpudos pelos quais se fazia passar, nas fases finais do refino, a água conduzindo material arenoso.

Os diamantes, então considerados propriedade real, tinham sua 
exploração controlada pela administração do Distrito dos Diamantes. O processo de extração não diferia fundamentalmente do usado na mineração do ouro em cascalho, e era também centrado na operação de lavagem, que exigia agora menor volume d'água:"para a lavagem do ouro é necessário que a água seja abundante; mas para a dos diamantes basta que ela seja límpida e que permita descobrir essas preciosas pedras no meio dos calhaus". (DD,p. 37-38). O serviço era feito por escravos, todos alugados a particulares; na época da viagem de Saint-Hilaire, a administração tinha cerca de mil escravos alugados (DD, p. 16.)

Essa descrição sucinta permite perceber duas características importantes dos trabalhos de mineração testemunhados pelo Naturalista. Primeiro, tratava-se de um processo que, para ter eficácia, exigia atenção e habilidade do operário. Sendo mal feita, a lavagem deixaria passar grande quantidade de ouro ou diamantes. De uma forma ou de outra, algo passava, dada a ineficiência das técnicas usadas (como observou mais de uma vez o Naturalista aos encarregados das lavras de ouro, os quais receberam suas críticas com indiferença); por isso mesmo os rejeitos das lavagens eram comumente falseados ou garimpados por mineradores pobres. No entanto, para minimizar as perdas, seria indispensável que os encarregados da lavagem se aplicassem com atenção a seu trabalho. Separar o ouro da ganga, ou os diamantes do cascalho era, tipicamente, uma tarefa em que o bom desempenho se relacionava muito mais com a qualidade do serviço do que com a quantidade do material processado; ou seja, uma tarefa "intensiva em habilidade", na classificação vista anteriormente.

Em segundo lugar, parece evidente não só que haveria inúmeras oportunidades de furtos, dado que os processos eram todos manuais, como essa possibilidade deveria parecer muito atraente a indivíduos sem renda, como os escravos — já que mesmo pequenas pepitas, ou diamantes de tamanho reduzido, representavam um valor considerável (principalmente os diamantes, muito mais valiosos, pelo peso, do que o ouro"). Em outras palavras, o custo de desviar partículas do metal e, mais ainda, pequenos diamantes, poderia parecer-lhes relativamente baixo, quando comparado com a probabilidade do ganho.

\footnotetext{
"Um a comparação de valores, aos preços da época, ilustra essa afirmativa: enquanto uma oitava de ouro $(3,6 \mathrm{~g})$ valia $1 \$ 200$, um quilate $(0,2 \mathrm{~g})$ de diamantes pequenos era vendido pela Coroa portuguesa a $7 \$ 200$ (MG, p. 49; DD, p. 18). Ou seja: uma relação próxima de cem para um, entre o valor da grama de diamantes e da grama de ouro.
} 
Em decorrência, duas atitudes seriam de esperar, por parte dos donos ou arrendatários de escravos: a adoção de medidas visando diminuir os furtos e o contrabando, fazendo aumentar seu custo por meio de penalidades rigorosas; e, por outro lado, o uso de incentivos positivos, mais do que a coerção, como forma de maximizar a eficiência da mãode-obra. Isso porque, como se viu acima, no caso de tarefas intensivas em habilidade os métodos coercitivos são, em princípio, menos eficientes, em comparação com o oferecimento de alguma forma de recompensa pela boa execução das tarefas. Os relatos de Saint-Hilaire confirmam essas suposições.

As precauções contra furtos registradas pelo Viajante eram mais rigorosas no caso dos diamantes, dado seu maior valor relativo. $\mathrm{Na}$ lavagem do cascalho diamantífero, cada oito escravos (ou seis, se o cascalho fosse muito rico) trabalhava sob o olhar fixo de um feitor; "se alguém dirige a palavra a um desses rígidos vigias, ele pode responder, mas sem voltar a cabeça". (DD, p. 38). A roupa desses cativos era reduzida ao mínimo, "um pedaço de pano de algodão amarrado ao redor das cadeiras"; se fizesse frio, permitia-se um colete, sem bolsos nem dobras. Ao fim do trabalho, uma revista minuciosa, incluindo a boca (ibid.). Havendo suspeita de que um deles tivesse engolido um diamante,"fazemno em seguida engolir três pedras comuns e não lhe restituem a liberdade senão depois de evacuadas as três pedras, sem que nenhum diamante tenha sido descoberto". (DD, p. 19). Além destas precauções, havia castigos rigorosos aos ladrões: chicoteados e postos a ferros os escravos (enquanto durasse o castigo, seus donos nada receberiam de aluguel); e degredados para a África, com os bens confiscados, os homens livres cúmplices do roubo, como intermediários ou contrabandistas.

Apesar de tudo, os furtos eram constantes, e nisso os escravos tinham "uma sutileza de causar inveja aos nossos melhores gatunos". (DD, p. 20). Um dos Intendentes dos Diamantes pretendera testar o escravo tido então como o mais "sutil", e prometera-lhe a liberdade caso conseguisse, sob a vigilância do próprio Intendente, surrupiar um diamante colocado no meio do cascalho. Poucos instantes depois de iniciar o trabalho de lavagem, o escravo tirou o diamante da boca e proclamouse livre, "se se pode acreditar na palavra dos brancos", (ibid.). No caso do ouro, o Naturalista retratou situação análoga. Com relação à lavra de Itabira, por exemplo, notou que "mau grado a vigilância dos interessados, a pilhagem dos trabalhadores é tão considerável, que três quartas partes do ouro que circula pelas tabernas da região provém dessa lavra". (MG, p. 121). Na vizinha mineração de Conceição, os proprietários, reconhe- 
cendo esse fato, tinham resolvido utilizar-se dele para minimizar seus prejuízos: "para recobrar uma parte do que lhes era furtado, [...] estabeleceram, na própria montanha, vendas por eles mantidas, e aonde os negros levavam uma parte do que furtavam". (MG, p. 124). Segundo o Viajante, esse expediente atingira seus objetivos, pois, "seguros de poder roubar mais ainda, [os escravos] imitavam a prodigalidade de seus senhores, e dissipavam o fruto dos roubos", (ibid.). Em algumas lavras, a pouca água disponível fazia com que o cascalho recolhido tivesse que ficar um bom tempo à espera da estação chuvosa para ser submetido à lavagem, o que facilitava os roubos (MG, p. 126).

No Distrito dos Diamantes, os feitores empunhavam chicotes, e ocorria a aplicação de açoites com o temido "bacalhau", como castigo de faltas graves - o que era, no entanto, vedado aos feitores, e reservado aos "administradores particulares", responsáveis por uma "tropa" de cem a duzentos escravos. Mas, havia também recompensas, que variavam segundo o tamanho dos diamantes encontrados. Para diamantes de uma oitava, dava-se alforria ao escravo, que passava a receber o equivalente ao aluguel antes pago a seu senhor. Para três quartos de oitava, uma alforria diferida para um tempo futuro; para pedras menores, chapéus, facas, coletes. (DD, p. 15-17).

As alforrias, contudo, eram raras; no ano anterior ao da viagem de Saint-Hilaire, 1816, houvera três (para um estoque total de cerca de mil escravos); em 1817, até outubro, nenhuma. Assim, é provável que o incentivo mais efetivo, para os escravos da mineração, fosse não tanto a perspectiva de alforria obtida diretamente como prêmio, ou de outras recompensas menores, mas sim a possibilidade de ganhos por meio do desvio subreptício das pedras ou do metal (o que podia também, ao final, levá-los à alforria). Era isso, com toda probabilidade, que fazia com que - apesar do regime duro e das condições de trabalho extremamente penosas - "quase todos [os escravos preferissem] a extração dos diamantes ao serviço de seus donos". (DD, p. 16).

Em suma, o quadro da organização do trabalho na mineração traçado pelo Viajante tem algumas similaridades com o sistema de plantation (especialmente no caso dos diamantes), mas também discrepâncias importantes. Existia o trabalho em equipes sob a vigilância do feitor; mas a coerção estava mais voltada a inibir os furtos do que a maximizar o ritmo e a intensidade do trabalho dos cativos. De fato, os senhores brandiam uma mistura de incentivos e de ameaças de punição, no propósito de maximizar a produção líquida (ou seja, a produção total menos as perdas decorrentes de furtos). De sua parte, os escravos tentavam 
maximizar seus próprios ganhos: uma mistura das recompensas recebidas e do resultado dos furtos que tivessem a habilidade de efetuar.

Assim, pelo visto, as relações senhor-escravo não eram, na mineração, dominadas pela violência unilateral. Com efeito, se Saint-Hilaire faz menção, nesse caso, a punições físicas severas, não fala propriamente de maus tratos, de crueldades praticadas no dia-a-dia da vida dos cativos (como fará depois, no caso de alguns engenhos de açúcar).

\section{O escravo na cana-de-açúcar}

Da agricultura típica de exportação, Saint-Hilaire só viu, praticamente, a da cana-de-açúcar. O café apenas então estava começando sua vigorosa expansão pelo Vale do Paraíba, e ele menciona isso de passagem, duas ou três vezes. ${ }^{12}$

Quanto à cana-de-açúcar, o naturalista viu plantações e engenhos, de vários tamanhos, em todas as províncias que percorreu. Os melhores engenhos eram os fluminenses, embora seu processo de fabricação de açúcar lhe parecesse - como aliás o da generalidade dos engenhos brasileiros - desatualizado e pouco eficiente (MG, p.26; DD, p. 200). A maior concentração de produção açucareira, nas regiões que visitou, estava nas vizinhanças da cidade de Campos, onde havia cerca de 400 engenhos (DD, p. 199).

O tratamento dos escravos pelos senhores de engenho, nessa região, impressionou-o muito mal. Já pernoitando num engenho, perto de Saquarema, em sua viagem rumo a Campos, fora alojado junto à moenda, e mal pudera dormir por causa do barulho do mecanismo, do vozerio dos escravos "e, mais fatigantes ainda, dos gritos dos feitores que ameaçavam incessantemente os escravos". (DD, p. 147). Mas, foi perto de Campos que o rigor e crueldade dos donos de escravos o surpreendeu:

12 Nos arredores de Macaé, na província do Rio de Janeiro, vários proprietários de engenhos haviam abandonado a cana pelo cultivo do café, que exigia menos benfeitorias e menos escravos, e se dava bem na região. No vale do Paraíba paulista, na região de Guaratinguetá, os novos fazendeiros de café prosperavam, havendo notícia de alguns que possuíam até 100 mil pés.Viviam, em geral, de forma modesta, não educavam os filhos; pareciam-lhe (ao contrário dos habitantes de Minas) ignorantes e pouco inteligentes; e tendiam a reinvestir todo seu lucro na compra de mais escravos, a fim de aumentarem suas plantaçóes. Perto de Jacaré, onde havia pouco não se queria saber senão de cultivar algodão e criar porcos, plantava-se agora muito café (DD, p. 185 e segs.; SV, p. 93, 100 e segs.). 
"Poder-se-ia supor que em Campos, onde os proprietários não se envergonham de se entregar aos trabalhos agrícolas manuais, os escravos, tornados de qualquer modo companheiros do homem livre, fossem tratados com doçura; mas infelizmente tal não se dá. Querem fazer açúcar cada ano mais, e assim sobrecarregam os negros de trabalho, sem se inquietar com o prejuízo que ocasionam a si próprios, abreviando a existência desses infelizes". (DD, p.201).

Verificou existirem, na área,"várias fazendas onde se vêem escravos doentes em conseqüência dos maus tratos recebidos, ao mesmo tempo que há sempre pessoas à procura de escravos, evadidos em conseqüência da insuportável vida que levam". (DD, p. 201.). Não havia qualquer cuidado para com as escravas que tivessem dado à luz: logo após o parto, "eram obrigadas a trabalhar nas plantações de cana, sob um sol abrasador", o que fazia com que seus filhos tivessem uma alimentação defeituosa; e Saint-Hilaire perguntava:"como poderiam as pobres criancinhas resistir às cruéis misérias com que a avareza dos brancos cercava seus berços?" (ibid).

Muitas fazendas, nessa área, adotavam o sistema tradicional de dar aos escravos, além do domingo, um dia adicional para plantarem suas roças e com isso produzirem seu próprio sustento - em lugar de fornecer-lhes refeições diárias. (Em um dos maiores engenhos de Campos, os escravos tinham de fato não mais do que três dias por quinzena para cultivar o necessário a sua subsistência $\left.{ }^{13}\right)$. O viajante condenou o sistema como desumano para com "os negros recém-chegados da costa da África, para os preguiçosos, os viciados, aqueles enfim, verdadeiramente numerosos, aos quais não é possível induzir à previdência". (DD, p. 202). ${ }^{14}$

\footnotetext{
Surpreendentemente, o administrador dessa fazenda gabou-se a Saint-Hilaire de que, com três dias de cultivo próprio por quinzena, seus escravos podiam mesmo produzir excedentes para venda, a ponto de alguns deles terem, eles próprios, comprado escravos. (DD, p. 209 ).

${ }^{14}$ f interessante notar que vários observadores da época julgaram que a adoção desse sistema - as vezes visto, modernamente, como uma "conquista" dos escravos - decorria do propósito de minimizar o custo de alimentação dos escravos, e tendia a penalizá-los, em lugar de os favorecer.Veja-se, por exemplo, as observações de Koster a respeito: o feriado aos sábados não bastava para viabilizar o autosustento dos escravos, a menos que eles dedicassem a isso também os domingos e os numerosos dias santos - que de outra forma seriam dias de folga. Ou seja, os escravos claramente saíam perdendo (v. Koster, 1816, p. 428). Aliás, aquele sistema
} 
É interessante especular sobre a razão que fez um observador atilado (embora preconceituoso) como Saint-Hilaire alimentar a expectativa ingênua de que os escravos fossem bem tratados no vale do Paraíba, por serem aí "de qualquer modo companheiros do homem livre".

Cabe lembrar, em primeiro lugar, que, quando o Naturalista percorreu a zona fluminense do açúcar, no segundo semestre de 1818 , já estava no Brasil havia mais de dois anos; nesse período, viajara principalmente por Minas Gerais, durante cerca de quinze meses. Tinha muito em mente, assim, uma comparação entre o que vira antes e que estava vendo agora. Ao dizer que os fluminenses não se envergonhavam do trabalho braçal, fazia um contraste com as atitudes que observara entre os mineiros. Na zona mineratória, onde os senhores "apenas vigiam os escravos e nada trabalham" - como se viu acima - os tarefas manuais eram vistas como coisa de escravo, abaixo da dignidade do homem branco, do proprietário. Exercer tais tarefas era vergonhoso: "tal é o sentido de vergonha dado a certos trabalhos que, para pintar a pobreza de um homem livre, diz-se que ele não dispõe de ninguém para ir buscar-lhe um balde de água [...,]" (DD, p.33). ${ }^{15}$ Mas, o mesmo não era verdade, julgava ele, na área rural fluminense. Perto de Cabo Frio, por exemplo, "os brancos, que formam quase toda a população, entregam-se sem acanhamento a serviços que um mineiro olharia como desonrosos", como buscar água e lenha ou carregar cargas. Ele atribuiu essa atitude, generalizadamente, a todos os fluminenses daquela área. Visitando, próximo de Campos, uma grande fazenda que fora dos jesuítas, então em decadência, acreditava que sua inevitável repartição em pequenas propriedades seria benéfica, pois nessa região "o pequeno proprietário não se acanha de trabalhar". (DD, p. 169, 207).

A parte dessas diferenças culturais, é importante notar uma outra. Trata-se do fato de que foi na região de Campos que Saint-Hilaire se viu, pela primeira vez, perante um autêntico sistema de plantation, com

já fora, mais de um século antes, verberado pelo jesuíta Benci, pela mesma razão: pretender que os escravos plantassem para comer significava obrigá-los a não guardar domingos e dias santos, e era portanto pecaminoso. "Se por faltar com o sustento dos escravos, os obrigais a procurá-lo nos domingos e dias santos: não vedes que pecais gravemente, contra o Terceiro Mandamento da Lei de Deus?" (Benci, 1954 [1700], p. 38).

${ }^{15}$ Percorrendo a região metalúrgica, Saint-Hilaire havia avisiado alguns homens brancos garimpando ouro, o que o levou a comentar:"Só a pobreza poderia tê-los feito calcar o preconceito que, principalmente nessa parte da província [de Minas], condena à ociosidade os homens da nossa raça". (MG, p. 119). 
a característica forma de organização do trabalho a ele associada. Ou melhor, foi aí que ele se deparou, pela primeira vez, com uma área em que esse sistema era preponderante, na organização da atividade produtiva. Isto era algo que não tinha visto em Minas - - nem, de fato, veria posteriormente. É plausível supor, assim, que sua surpresa, ao testemunhar relações senhor-escravo baseadas predominantemente na coerção, na zona açucareira do Rio, decorria de que isso era uma novidade para ele. Ele já tinha visto, e veria ainda, grandes fazendas com engenhos de açúcar. Mas, em nenhuma outra área que visitou, a escravidão estava acompanhada dos outros dois elementos do trinômio famoso - latifúndio, monocultura - como na região de Campos.

É significativo que não se repitiu qualquer menção de Saint-Hilaire a maus tratos de escravos empregados na agricultura, fora da área dos grandes engenhos do Vale do Paraíba fluminense. Ao contrário, quando o Viajante escreveu algo a respeito, havia elogios. E mesmo na área de Campos, havia exceções. O guarda-mor Antônio Feliciano, dono de uma moenda e de uma destilaria de cachaça (onde adotara "meios excelentes para diminuir a mão-de-obra"), perto de Vila do Príncipe, "parecia tratar com muita brandura" seus escravos. O capitão-mor Francisco Pinto,"homem inteligente e bom agricultor", que seguia os métodos de administração introduzidos na região pelos jesuítas, "tratava seus negros com humanidade", em sua propriedade perto de Vitória, no Espírito Santo, onde plantava cana-de-açúcar e algodão. Aí, durante o primeiro ano após o parto, a escrava "ficava em casa tecendo algodão e amamentando o filho recém-nascido". O comandante Joaquim Alves, de Meia-Ponte (hoje Pirenópolis), em Goiás, que vendia algodão para o Rio e a Bahia, e produzia açúcar e cachaça para consumo na Província, adotava a norma de alimentar e vestir bem os escravos, tratá-los quando doentes - ejamais deixá-los ociosos. Em sua fazenda, as mães também eram dispensadas de trabalhar nas plantações enquanto amamentavam os filhos; depois, as crianças ficavam todas a cargo de uma só escrava. (MG, p.166; ES, p. 48; GO, p. 98-99). Essa ausência de referências quando se considera que o Naturalista sempre foi tão veemente na condenação dos maus tratos que presenciou — , constitui um indício forte de que ele efetivamente não tenha chegado a ver, ao menos na agricultura, outros exemplos de formas rigidamente coercitivas de escravidão.

Em Minas Gerais - onde se estimou haver, na época, cerca de mil engenhos $^{16}$ - os relatos de Saint-Hilaire registram sua passagem por

Costa Filho, 1963, p. 307 . 
muitos deles. Todos, ou quase todos, eram tecnicamente inferiores aos engenhos fluminenses. Estes tinham os cilindros da moenda revestidos de chapas de ferro, enquanto que nos engenhos mineiros os cilindros eram de madeira; ele viu, em Minas, um só engenho - no atual município de Itabira - com aquele tipo de revestimento (MG, p. 65; DD, p. 56; Costa Filho, 1963, p. 242). E eram, em sua maioria, engenhos pequenos, muitos deles fabricando apenas rapadura ou cachaça (o que envolve menos investimentos e mão-de-obra do que o fabrico de açúcar). Os donos de engenhos vizinhos da zona mineratória, principalmente, achavam mais lucrativo dedicar-se à produção de cachaça, dado o grande consumo por parte dos escravos da mineração (MG, p. 167). Poucos engenhos mineiros eram movidos a água; a maioria, à força de bois.

De fato, entre os inúmeros engenhos de Minas que mencionou, poucos teriam sido chamados por Antonil de "engenhos reais". ${ }^{17}$ Seriam certamente dignos dessa classificação o engenho de Itabira, na fazenda do Sr. Domingos Afonso ("uma das mais importantes da Província", com 130 escravos); o da fazenda Itanguá, perto de Vila do Príncipe (Serro); e talvez o da fazenda Santo Elói, perto de Formigas (Montes Claros). Mas, deve-se notar que, nessas fazendas - como, aliás, na generalidade das propriedades agrícolas de Minas que o Autor descreve não se praticava a monocultura. Exploravam-se, para geração de renda, também outras linhas de atividade agrícola (além, é claro, da produção para auto-consumo, universalmente disseminada). A fazenda de Domingos Afonso, com seus 130 escravos, produzia também milho, vendido aos tropeiros e viajantes numa venda próxima, "uma das mais importantes [da] região"; a de Itanguá tinha também um engenho para extração de óleo de mamona, movido a roda d'água (o que sugere escala de produção comercial); e o respeitável rendimento que a fazenda de Santo Elói proporcionava a seu proprietário provinha não só do açúcar, como da criação de gado. (DD, p. 56; MG, p.198-99, 324-25). No que se refere ao tratamento dado aos escravos, Saint-Hilaire não encontrou nessas fazendas, que descreve com certo detalhe, nada que julgasse digno de menção. Indício de que não havia nem coerção rigorosa, nem benevolência especial.

Em São Paulo, onde a cana-de-açúcar se difundira muito nos anos precedentes - primeiro na região de Itu, depois em Campinas e Jundiaí -, os engenhos eram, regra geral, de pequeno porte. O Autor foi informado de que as cidades de Itu, Jundiaí, Campinas, Sorocaba, Porto

Cf. Antonil 1982 [1711],p. 69. 
Feliz e a paróquia de Piracicaba tinham exportado, em conjunto, 300 mil arrobas de açúcar em 1818. Dado que apenas em Campinas e Itu havia cerca de 200 engenhos (e que um engenho de vinte escravos podia produzir 2 mil arrobas por ano), isso indica a existência de um grande número de pequenos engenhos na região (SP, p. 100,175,180). Em Campinas, "as propriedades que à época de minha viagem eram consideradas importantes empregavam cerca de vinte escravos." (SP, p. 110). O quadro que isso sugere é de uma organização da produção açucareira distinta da do regime de plantation das grandes propriedades.

Mas, o que mais surpreende nos relatos do Autor - à luz do paradigma corrente na literatura sobre a produção escravista de açúcar — é a referência a uma categoria de engenhos de natureza diametralmente oposta à dos usualmente descritos: a dos engenhos "pobres", onde proprietários de poucos recursos cultivavam e processavam a cana, em escala modesta, e tinham um nível de vida que não estava muito distante do de seus próprios escravos. Em Goiás, dirigindo-se às termas de Caldas, Saint-Hilaire relata:

"Depois de ter percorrido 4 léguas a partir do Sítio de Gregório Nunes, parei numa propriedade denominada Sítio de Francisco Alves. Havia ali um engenho-de-açúcar ao ar livre, como são geralmente os dos colonos de poucas posses, e uma dúzia de casinhas esparsas. Uma delas pertencia ao proprietário e as outras eram habitadas por escravos e agregados. Todas, porém, tinham uma aparência igualmente miserável, sendo impossível distinguir a do dono. Os trajes dos moradores desses humildes casebres combinavam perfeitamente com a miséria que eles indicavam. O mais bem vestido trazia apenas calções de algodão e uma camisa do mesmo tecido, traje habitual dos habitantes mais pobres do interior do Brasil". (GO, p. 110)

Nada poderia ser mais afastado do quadro da sociedade patriarcal do açúcar, tão amplamente retratado nos livros de Gilberto Freyre. O relevante, aqui, é que esse não era um caso isolado, mas sim um exemplo extremo de uma realidade bastante encontradiça nas regiões percorridas pelo Autor (como se verá abaixo): a da produção agrícola escravista, com fins comerciais, fora do sistema de plantation.

$\mathrm{Na}$ mesma região, próximo do rio Paranaíba, o Naturalista deparouse com outro exemplo disso, aparentemente num nível superior de produtividade: 
"Ainda nas proximidades do [Sírio do Riacho], passei diante da Fazenda dos Casados, onde há um engenho-de-açúcar. Ao redor da casa se agrupavam várias outras, pertencentes aos agregados [...] Desnecessário é dizer que a casa do proprietário diferia pouco das outras, e mesmo da senzala. Essa forma de igualdade, generalizada nessa parte da Província, nada provava senão uma uniforme rusticidade de hábitos. Os tropeiros encontram nessa fazenda as provisões de que necessitam, mas um mercado tão precário não seria suficiente, dada a importância da propriedade. Seu dono enviava também a Araxá açúcar, cachaça e outros produtos, em lombo de burro. A viagem não levava mais que doze dias". (GO, p. 123)

Também na região da Serra da Mantiqueira, perto da divisa entre Minas e São Paulo, o Autor refere-se a outro "engenho pobre";

"Muito tempo antes de se alcançar a Raiz da Serra, passa-se por uma casinhola. Aquela onde paramos é a primeira que se vê logo em seguida. Deram-nos pousada numa construção meio desabrigada, mas nada temos que nos queixar, pois o nosso hospedeiro não está mais bem instalado, embora possua negros e até um engenho de açúcar". (SV, p. 69)

\section{O escravo em outras formas de agricultura}

A grande maioria das fazendas mencionadas por Saint-Hilaire, na vasta região por ele percorrida, dedicavam-se a várias formas de cultivo e criação (mesmo se se consideram apenas as atividades que geravam produtos comerciáveis). Isso é particularmente verdade para Minas Gerais, a Província por onde viajou mais demoradamente. Nessas fazendas, ele viu escravos empregados em vários tipos de plantação além da de cana-de-açúcar: na de milho, mandioca, arroz, algodão, feijão, trigo, frutas e legumes.

Inúmeros fazendeiros com propriedades próximas a estradas plantavam milho para venda aos viajantes e tropeiros, para alimento de seus animais. Era comum que estabelecessem vendas à beira da estrada - onde em geral não se oferecia mais do que milho e cachaça - e ao lado delas, como chamariz, construía-se um rancho, no qual os viajantes podiam pernoitar sem custo. Foi, no mais das vezes, pousando em ranchos desse tipo que Saint-Hilaire percorreu seus 15 mil quilômetros pelo Brasil. Em certas localidades mais isoladas, o poder de monopólio era am- 
piamente explorado, e o preço do milho subia muito acima do praticado nas povoações, o que sugere que o negócio podia prover lucros substanciais para seus produtores.

O escravo com quem manteve o diálogo, que tanto o impressionou, sobre o estado de espírito dos cativos (veja-se acima na p. 13), cuidava de uma plantação de milho, próxima à estrada e afastada da casa de seu senhor, e dormia, sozinho, numa choupana em meio ao milharal (MG, p. 53). Isso dpifica as condições de trabalho de grande parte da mão-deobra escrava aplicada à produção do milho. Essa cultura não se coadunava, em geral, com o sistema de trabalho quase de "linha de montagem", característico do regime de plantation. Semeado em setembro, o milho não exigia muitos cuidados até a colheita, em abril: em geral apenas uma capina em outubro, outra em janeiro (quando se plantavajunto o feijão), e uma final um mês mais tarde. A debulha era manual ou semimanual, nos "batedores" (MG, p. 106). Nada que prendesse os escravos, ao longo do ano, num ciclo contínuo de atividades intensivas em esforço, como era o caso nos engenhos e nos cafezais típicos (Versiani, 1994).

Vários exemplos do uso de escravos no cultivo do milho podem ser encontrados nos relatos do Naturalista. Por exemplo, perto de Santa Bárbara, em Minas, ele viu escravos plantando milho num campo adubado com esterco de gado, o que era excepcional e chamou sua atenção (o proprietário tinha 700 cabeças de gado, e desenvolvera uma técnica simples de uso do estrume). As margens do Araçuaí, uma plantação de milho e feijão, com duzentos escravos, fora destinada a fornecer alimentos para os escravos de uma exploração de diamantes (MG, p. 92, 301).

$\mathrm{Na} Z$ Zona da Mata mineira, perto de Aiuruoca, ele assinalou que a produção de milho e feijão, com utilização de mão-de-obra escrava, embora se destinasse ao consumo local, relacionava-se à principal atividade geradora de renda da região: a criação de gado e de porcos, para possibilitar a venda de derivados, queijo e toicinho, no Rio de Janeiro: ${ }^{18}$

"Entre S.João e Aiuruoca colhem-se principalmente milho e feijão; mas os gêneros não saem da região. A criação de gado e porcos

\footnotetext{
${ }^{18}$ É interessante notar que essa passagem de Saint-Hilaire substancia uma hipótese colocada por Slenes: a de que parte da mão-de-obra escrava do século XIX, em Minas, estava engajada numa produção agrícola que, embora não fosse diretamente exportada para fora da Província, servia de insumo para produtos exportados como o toicinho e os queijos - e era, portanto, indiretamente, uma atividade dependente da demanda externa (Slenes, 1985).
} 
forma a principal ocupação dos agricultores e quase que sua única fonte de renda. Cada qual possui uma tropa de burros e envia ao Rio de Janeiro [toucinho] e queijos. Na paróquia de Aiuruoca e arredores, [...] os escravos estão para os homens livres na proporção de um para três. Os escravos são com efeito muito menos necessários na região onde se cria gado do que naquelas em que se cultiva a canade-açúcar e onde se lavra o ouro". (SV, p. 54)

Em outras culturas comerciais, como a do algodão, o Autor testemunhou igualmente o emprego de mão-de-obra escrava. Como numa fazenda na região de Peçanha, Minas Gerais, onde o produto era vendido a comerciantes de Vila do Príncipe e de outras localidades, pago "em dinheiro à vista" (MG, p. 172). Ou na já citada propriedade do comandante Joaquim Alves, perto de Meia-Ponte, em Goiás, onde o algodão produzido era exportado para o Rio de Janeiro e para a Bahia (e onde o Comandante mantinha uma venda com quinquilharias de agrado dos negros, a serem trocadas pelo algodão que estes produziam nos domingos - um modo engenhoso de mantê-los produtivos em seus dias de folga) (GO, p. 98-99). Naquela época, o cultivo do algodão, similarmente ao do milho ou do feijão, não exigia uma organização de produção no regime de plantation. O algodoal requer pouco trato: uma limpa de seis em seis meses, que; mesmo assim, era um trabalho "feito com pouca canseira, pois em lugar de revolver a superfície do solo, como se faz nos campos de milho e trigo, contentam-se em cortar rente as ervas daninhas." (MG, p. 172). Dessa forma, podia-se economizar mão-de-obra escrava, usando-a simultaneamente no cultivo do algodão, do feijão e do milho. "Um negro encarregado de cuidar do espaço de terreno plantado de algodoeiros, que se semearia com um alqueire de milho, pode, ao mesmo tempo, cultivar uma igual extensão de terra em milho e feijão." (ibid).

Em outras propriedades os escravos trabalhavam numa mistura mais complexa de cultivos, envolvendo rotação. Na fazenda do capitão-mor Francisco Pinto, no Espírito Santo - que, como mencionado, tratava seus escravos "com humanidade" —, alternava-se algodão, cana-de-açúcar associada a milho e feijão, e algodão. Aí o Viajante viu escravos de ambos os sexos envolvidos num plantio de mandioca: os escravos preparavam o terreno, cavando buracos onde as escravas enterravam talos da planta (ES,p. 49-54). 


\section{Escravos, gado e porcos}

Referindo-se ao uso da mão-de-obra escrava na pecuária, em Minas Gerais, Saint-Hilaire fez uma distinção entre o norte e o sul da Província. No norte - em particular na região a leste do Rio São Francisco, perto da atual cidade de Montes Claros - prevalecia uma opinião convergente com a visão tradicional da historiografia, a de que escravos e gado não se misturam bem. Nessa área,

"Em geral, não se gosta de confiar as funções de vaqueiro a escravos, porque os que as exercem vivem ordinariamente longe das vistas do senhor. Os vaqueiros são muito comumente os próprios filhos do proprietário, ou então homens livres a quem se dá o terço do produto do produto do rebanho". (MG, p. 314).

No sul, no entanto, no vale do Rio Grande, era usual a utilização de escravos no trato do gado. ${ }^{19}$ O Naturalista, de certa forma, associava essa diferença ao fato de que o regime de exploração do gado era, aqui, mais intensivo em mão-de-obra do que no norte,ficando os animais (e portanto os escravos) restritos a uma área mais próxima da sede da fazenda, e da vigilância do dono:

"Enquanto que no sertão oriental do S. Francisco os vaqueiros são homens livres, que vivem geralmente longe dos olhos dos patrões, [na região do Rio Grande] o cuidado dos animais é normalmente confiado a escravos. Como acontece em todo o resto do Brasil que percorri, na região do Rio Grande não se sabe o que seja um estábulo. Todavia, os animais não ficam entregues a si mesmos, como ocorre no sertão. Os fazendeiros que se dedicam em escala maior à criação de gado dividem suas pastagens em várias partes, seja por meio de fossos, seja por palissadas [sic] que tenham pelo menos a altura de um homem. Uma dessas divisões é para as vacas leiteiras, outra para os bezerros, uma terceira para as novilhas e finalmente a quarta para os touros". (SF.p. 50-51).

Assim, numa fazenda perto de Carrancas, na região de São João del

\footnotetext{
"Cabe referir aqui a controvérsia existente na literatura sobre o uso da mãode-obra escrava na pecuária; veja-se, par exemplo, Gorender (1970, cap.20). A evidêcia trazida por Saint-Hilaire é importante, nesse contexto.
} 
Rei, onde pernoitou, escravos e escravas faziam a ordenha das vacas, e usavam cuias para encher de leite "pequenos barris cintados de aros de ferro" (SV, p. 48). Sempre muito severo em seu julgamento das práticas da agropecuária brasileira, o Viajante foi condescende em acrescentar, nessa passagem, um raro elogio:

"O gado dos arredores do Rio Grande tem justificada fama, graças ao tamanho e força. Alimentado em ótimos pastos, as vacas dão leite quase tão rico em nata quanto o das nossas montanhas. Com ele se faz grande quantidade de queijos exportados para o Rio de Janeiro". (SV,p. 48).

Tratava-se aqui, também - tal como no caso da vizinha região de Aiuruoca, mencionado acima - do emprego de escravos numa atividade diretamente ligada ao comércio interprovincial.

Outros exemplos de escravos lidando com vacas e porcos podem ser acrescentados, não restritos à Zona da Mata mineira. Na fazenda de Dona Tomásia, entre Piui e a serra da Canastra, que era "de extensão considerável", Saint-Hilaire viu "vários escravos, gado vacum e numerosos porcos" (SF, p. 75). Em toda essa região próxima de Formiga, ele viu muitos suínos nas fazendas; "são eles que constituem a principal riqueza dos arredores de Formiga", esclarecia. Os porcos dessa região eram comumente levados em varas até o Rio de Janeiro (SF, p. 74). Perto de Franca, em São Paulo, viu escravas ordenhando vacas, na fazenda Paciência (SP, p. 95).

Mas, o emprego de escravos na pecuária não estava restrito apenas a situações em que era possível a vigilância próxima de seus senhores. O próprio Viajante relata casos em que os animais eram inteiramente confiados a cativos, sem que o dono sequer morasse na propriedade. Essa situação, tão agudamente divergente do modelo clássico "de escravismo, foi testemunhada por ele, por exemplo, na região de Macaé, no litoral fluminense. Aí, ele parou no sítio do Pires, que era habitado por um escravo de fazenda vizinha,"a quem seu dono havia confiado a guarda de duzentas ou trezentas cabeças de gado, espalhadas pelas pastagens dos arredores". Sozinho no sítio, o escravo dedicava-se a criar galinhas e pescar nas lagoas próximas (DD, p. 189). Pouco adiante, o caso se repete: o sítio do Andrade, dependência de uma grande fazenda que fora propriedade dos jesuítas, perto de Campos (a fazenda do Colégio), era "apenas habitado por dois escravos da fazenda do Colégio, encarregados de cuidar do gado que vive nos arredores" (DD, p. 190). 
Essa situação - de proprietários absenteístas, e criações a cargo de escravos - foi igualmente observada por Saint-Hilaire em outras regiões. Referindo-se à zona entre Itapetininga e Itararé, no sul de São Paulo, afirmou:

"Existem na região algumas propriedades de considerável importância, onde é feita a criação de gado. Mas, ao passo que em Minas os grandes proprietários residem geralmente nas suas fazendas, os dali as deixam entregues a administradores e até mesmo a escravos". (SP,p. 207).

Perto de Itapeva, ele pernoitou, sucessivamente, em duas fazendas onde esse tipo de relação senhor-escravo era observado:

"A propriedade de Fazendinha, onde parei (23 de janeiro), estava entre as que eram chamadas defazendas de criar, por ser dedicada à criação de gado. Pertencia a uma senhora de Sorocaba, que mantinha ali um feitor e alguns escravos, mas nunca vinha à propriedade". (SP, p. 222).

No dia seguinte, chegou à fazenda de Perituva, que "pertencia a um homem muito rico de São Paulo, que jamais aparecia ali, e deixava seus rebanhos a cargo de seus escravos" (ibid.).

Tratava-se aqui de uma atividade "intensiva em habilidade" no mais alto grau: esses escravos agiam, de fato, como co-administradores das propriedades. Nada mais distanciado do escravismo de plantation.

\section{Relações senhores-escravos nas províncias do Sul}

As menções de Saint-Hilaire a propriedades deixadas inteiramente a cargo de escravos repetem-se nos relatos de sua viagem pelas províncias do sul do País. Nessa região - os atuais Estados do Paraná, Santa Catarina e Rio Grande do Sul - ele viu o trabalho cativo ser utilizado em propriedades com tipos diversos de exploração, em geral incluindo gado vacum (especialmente nos Campos Gerais do Paraná e no Rio Grande), e várias culturas, com predominância variada, nas diversas áreas que atravessou (especialmente trigo, milho, mandioca, feijão e arroz). Em geral, um pequeno número de escravos em cada propriedade. A cana de-açúcar, antes florescente em Santa Catarina, achava-se em decadência. Ou seja: o Autor não teve, certamente, ao percorrer as províncias do 
Sul, muitas oportunidades de ver mão-de-obra escrava organizada segundo o regime de plantation.

Não coincidentemente, suas referências sobre a forma de tratamento dos escravos são especialmente favoráveis, nestes seus relatos. E, em particular, nota-se uma correlação entre os exemplos de relativa autonomia dos cativos, na administração das propriedades, e uma avaliação positiva de seu nível de bem-estar. O que é natural: seria inconcebível que se aplicasse um tratamento coercitivo a escravos a quem se confiava toda uma propriedade. É evidente que deveriam prevalecer, nesses casos, incentivos positivos, e não a coerção violenta. Em algumas passagens, o Viajante chega a ser entusiástico, ao mostrar o quão amenas eram as condições de vida dos escravos, nas províncias do Sul.

Por exemplo, na fazenda de Caxambu, próxima da atual cidade de Jaguariaíva, no Paraná-"uma fazenda que teria sido considerada muito aprazível mesmo num país civilizado" — , onde teve que permanecer por cinco dias, retido pela chuva, ele foi tratado "de maneira esplêndida" (SC, p. 39). O proprietário estava ausente, mas um escravo - cortês, satisfeito da vida, seguro de sua autoridade - fez as honras da casa:

"Era servido pelo capataz, que, na ausência do dono, administrava a fazenda, e que no entanto não passava de um escravo. Esse homem não tinha, certamente, nada de que se queixar do patrão, pois parecia muito satisfeito. Era cortês sem ser servil, e embora dirigisse os outros escravos com autoridade, demonstrava para com eles uma bondade extrema", (ibid).

O mesmo quadro se repetiu numa fazenda próxima, a do Tenente Fugaça: proprietário ausente, escravos contentes e com uma postura digna:

"O proprietário estava ausente no momento de minha chegada, mas fui muito bem acolhido por seus escravos. Suas maneiras corteses e o contentamento que traziam estampado na face haviam feito com que eu os tomasse inicialmente por homens livres. Mas, tratava-se de escravos, que me fizeram os maiores elogios ao seu amo. Depois disso já não me surpreendia vê-los tão satisfeitos e tão prontos a servir". (SC, p. 42).

Deixando um pouco de lado seus preconceitos racistas, o Naturalista concluiu: "Se muitas vezes os negros têm um ar melancólico, sofredor e 
estúpido, e se chegam mesmo a se tornar desonestos e impudentes, é porque são maltratados", (ibid).

No Rio Grande do Sul, Saint-Hilaire teve a mesma experiência, em mais de uma estância. Na de José Correia, perto da Lagoa Mirim, onde pousou, o proprietário estava ausente, e ele encontrou apenas um negro, que se alimentava somente de carne, sem farinha ou pão, "como é useiro tratar-se os escravos nesta região." (RS, p. 84). Na Estância de Santos Reis, nas vizinhanças de São Borja, também o proprietário estava ausente, e o Viajante foi igualmente recebido por um negro, "muito delicado", que, quase como se fosse um proprietário, discorreu sobre a boa qualidade das terras da região para a agricultura, lamentou que a ferrugem atacasse o trigo, e explicou que se desistira, ali, da criação de gado devido aos roubos pelos índios da região. (RS, p. 130).

Em suma, bem alimentados, gozando às vezes de apreciável grau de autonomia em seu trabalho, vivendo uma vida saudável de exercícios, no trato do gado, os escravos do Rio Grande do Sul tinham, para o viajante, uma situação privilegiada:

"Não há, creio, em todo o Brasil, lugar onde os escravos sejam mais felizes do que [no Rio Grande do Sul]. Os senhores trabalham tanto quanto os escravos, mantêm-se próximos deles e tratam-nos com menos desprezo. O escravo, com carne à vontade, não é mal vestido, não anda a pé e sua principal ocupação consiste em galopar pelos campos, cousa mais sadia que fatigante. Enfim, eles fazem sentir aos animais que os cercam uma superioridade consoladora de sua condição baixa, elevando-se aos seus próprios olhos". (RS, p. 47).

A exceção a essa regra ocorreu entre os escravos das charqueadas, onde eram "tratados com rudeza". Na charqueada visitada por SaintHilaire, o proprietário, embora "tido como um dos xarqueadores [sic] mais humanos, só fala aos seus escravos com exagerada severidade, no que é imitado por sua mulher; os escravos parecem tremer diante de seus donos". (RS,p. 73). Consciente do conflito entre essa apreciação e a generalização que antes fizera sobre o tratamento de escravos no Rio Grande, o Naturalista justifica a diferença pelo fato de que, enquanto em cada estância há poucos escravos, nas charqueadas eles são muitos, e de pior qualidade:

"Afirmei que nesta Capitania os negros são tratados com bondade, e que os brancos com eles se familiarizam mais que em outro pontos 
do País. Referia-me aos escravos das estâncias, que são em pequeno número; nas xarqueadas a coisa muda de figura, porque sendo os negros em grande número e cheios de vícios, trazidos da Capital, torna-se necessário tratá-los com mais energia", (ibid.).

\section{Senzalas sem casas-grandes}

Um outro aspecto das relações entre senhores e escravos que ressalta dos relatos de Saint-Hilaire é a freqüente referência ao fato de que as moradias de uns e de outros, em muitas propriedades rurais, diferiam pouco em aspecto, e mesmo em nível de conforto. Ou seja, uma distância social relativamente menor, na aparência, entre os cativos e seus donos, do que a usualmente associada ao paradigma "casa grande e senzala". Já nos referimos acima a esse fato no caso dos engenhos "pobres", como os que o Autor descreveu na província de Goiás. Essa era, na época, uma região economicamente decadente, e poder-se-ia supor que a menor distância aparente entre escravos e senhores fosse facultada pelo empobrecimento geral associado à redução da atividade produtiva e do comércio. Mas, as referências do Viajante não se limitam a regiões estagnadas; também em áreas ativamente engajadas em cultura e criação para fins comerciais ele nota esse padrão. Especialmente no sul de Minas Gerais e no Rio Grande do Sul.

Em Minas Gerais, no seu percurso pela comarca de São João del Rei e pelo vale do Rio Grande, que o levou a Araxá e Paracatu, ele teve ocasião de fazer várias menções desse tipo. Na fazenda das Laranjeiras, próxima do Rio Grande, anotou: "A propriedade conta com um alojamento bastante vasto para os escravos, mas a aparência da casagrande é absolutamente miserável. [...] As paredes de barro nunca tinham sido caiadas". (SF, p. 60). A observação se repete para outra fazenda não distante dali, perto de Piuí:

"A propriedade era de extensão considerável e vi aí vários escravos, gado vacum e numerosos porcos. Entretanto, em meio a várias casinhas que serviam de celeiros e senzalas, a dona da fazenda ocupava uma miserável cabana construída sem os mínimos requisitos de estética e conforto, cujo mobiliário consistia apenas numa mesa e alguns bancos rústicos". (SF, p. 75)

$\mathrm{Na}$ fazenda em que pernoitou em seguida, encontrou um quadro análogo: 
"A fazenda tinha uma terreno imenso cercado de paus e vários casebres onde dormiam os escravos e se guardava a colheita, etc.,mas procurei em vão pela casa do dono. Ele também morava numa miserável choupana, que em nada diferia das outras". (SF, p. 99).

Para o Viajante, esse era um atributo geral das fazendas da região. Como menciona, numa fazenda por onde passou, um pouco mais adiante - fazenda grande, currais e celeiro amplos, escravos - : "como sempre, porém, a casa do proprietário é pequena e em péssimo estado de conservação". (SF, p. 107). Note-se que ele percorria uma região dedicada, em geral, à criação de gado e porcos, inclusive para venda fora da Província. Um comércio lucrativo e próspero, como muitas vezes refere. Não eram, certamente, fazendas decadentes.

Referindo-se agora a uma propriedade já próxima de Paracatu, ele novamente generaliza, atribuindo a modéstia das moradias dos fazendeiros a uma tendência geral, à falta de ordem:

"Vi ali vários negros, e seu proprietário [...] me pareceu gozar de uma certa prosperidade. Entretanto, sua morada era constituída por um casebre muito mal tratado, pois, com o já tive ocasião de dizer, a desordem caracteriza todas as propriedades que encontrei espalhadas por esses sertões". (SF, p. 142).

Nas estâncias sul-riograndenses, onde o número de escravos era em geral pequeno, como foi visto acima, Saint-Hilaire menciona várias vezes a pouca diferenciação entre o modo de morar dos escravos e o dos senhores. Perto de Viamão, pára em estância com "uma casinha mal construída, de pau-a-pique e barro, mas coberta de telhas; [...] aos lados laranjeiras, currais e algumas casas de negros". (RG, p. 23). Mais ao sul, numa região de cultivo de trigo, surge outro exemplo extremo dessa indiferenciação:

"Parei em uma estância que se compõe de miserável palhoça, toda aberta, e de algumas casas de negros. A casa principal é ocupada por um homem ainda muito jovem e tudo nela estava em grande desordem". (RG, p. 87)

E novamente, na entrada subseqüente de seu diário de viagem:

"A estância onde parei compõe-se de uma choupana, habitada 
pelo proprietário, de outra para os escravos e de uma cobertura que abriga os utensílios agrícolas. Fui recebido em uma sala cujo mobiliário consiste apenas em duas camas, um banco e uma mesa." (ibid)

Outras citações poderiam ser acrescentadas (por exemplo: RS, p. 162, 179; SC, p. 34). Mas é desnecessário; as referências acima bastam para mostrar que Saint-Hilaire encontrou, em boa parte de seu extenso percurso pelo País, um quadro em que a aproximação entre cativos e seus donos - sem se restringir à reza, à dança, ao concubinato, ao eventual trabalho conjunto ou co-administração das propriedades estendia-se às condições de moradia. Tanto uns como outros moravam mal (ou mesmo miseravelmente, como escrevia o Naturalista). Havia senzalas, mas nada que se parecesse com as casas-grandes patriarcais. Esse é um dado significativo, pois indica também uma menor distância social entre senhores e escravos, coerentemente com o que foi visto nas seções precedentes. E que contribui, portanto, para evidenciar que as formas de relação senhor-escravo que nosso viajante testemunhou estavam, na quase totalidade dos casos, muito distantes das associadas às descrições tradicionais do regime escravista.

\section{Principais conclusões}

Quais os escravos que Saint-Hilaire viu? O levantamento sistemático das referências sobre escravidão nos seus minuciosos (e sem dúvida fidedignos) relatos de viagem, feito acima, deixa claro um ponto: o Viajante teve pouquíssimas oportunidades, ao longo de quase cinco anos e 15 mil quilômetros de jornadas pelo Centro-Sul do Brasil, de testemunhar o escravismo de plantation. Ou seja, mão-de-obra escrava aplicada à produção agrícola (tipicamente, de lavouras como açúcar, café, algodão), conduzida em escala suficiente para permitir uma organização do trabalho em turmas de escravos, dedicadas à execução de tarefas intensivas em esforço, a cada turma correspondendo um supervisor direto, que dita e fiscaliza o ritmo e a eficácia da execução das tarefas. Um arremedo de linha de montagem, em que a cadência do trabalho é dada não pela velocidade da correia transportadora, mas pela ação coercitiva do feitor, que é exercida pela ameaça, potencial ou efetiva, de castigos físicos.

O escravo típico dos relatos de Saint-Hilaire, representativo dos que ele encontrou em suas viagens e descreveu, é bem diferente desse. O que transparece em seus livros é que a escravidão predominante, modal 
— portanto "típica" — era, nas áreas que percorreu, associada a tarefas intensivas em habilidade nas fazendas de produção diversificada, na criação de porcos ou de gado leiteiro, nos pequenos engenhos de açúcar, e mesmo na mineração; a dos cativos trabalhando ao lado do senhor, às vezes convivendo com ele, ou mesmo trabalhando sozinhos, sem qualquer vigia, eventualmente fazendo as vezes de administradores da propriedade.

Isto é, em si, um fato significativo. É comum, como se sabe, associarse a escravidão negra à produção agrícola para exportação, em grandes propriedades rurais. O trinômio "latifúndio-monocultura-escravidão" costuma ser apresentado, em livros escolares, como uma síntese das características do sistema produtivo num período amplo de nossa história econômica; no imaginário popular, sem dúvida, a figura típica do escravo é a de um negro trabalhando, sob a ameaça do chicote do feitor, numa plantação de açúcar ou de café. Em contraste com isso, o quadro descrito pelo Viajante - aparentemente, aplicável a uma extensa região do País, no início do século XIX - é o de uma outra escravidão.

Cabe referir que o pressuposto de que a forma básica de escravidão negra corresponde à utilização de mão-de-obra cativa em regime de plantation não se restringe à visão leiga, mas costuma aparecer também na literatura técnica sobre escravismo, explicita ou implicitamente. A verificação da existência de formas alternativas de uso da força de trabalho escrava é, às vezes, apregoada como um desafio à visão tradicional sobre o escravismo, como evidência de uma outra, ou "nova" escravidão. ${ }^{20} \mathrm{O}$ debate suscitado, na década de oitenta, pelo artigo de Martins Filho \& Martins (1983) sobre o escravismo em Minas Gerais no século XIX, é um exemplo disso. Embora a tese central do artigo - de que o uso da mão-de-obra escrava, no caso, não estivesse ligado ao setor exportador da economia - tenha sido rebatida de várias formas, em geral os críticos concordaram com os Martins quanto ao fato de que a economia mineira seria um caso excepcional, no que respeita à pouca importância relativa da escravidão em regime de plantantion. ${ }^{2 t} \mathrm{Na}$ conclusão de seu trabalho, um dos críticos afirmou: "Seja a Província uma economia autárquica ou profundamente ligada às atividades de exportação, certamente é um caso à parte, e um desafio aos modelos existentes da escravidão moderna". (Slenes, 1985:63). Ora, os relatos de Saint-Hilaire sugerem justamente

\footnotetext{
${ }^{20}$ Notar, por exemplo, o subtítulo de um livro sobre escravos de ganho, publicado nos anos oitenta: A Nova Face da Escravidão (Silva, 1988).

Ver Martins Filho \& Martins (1983, 1984); Slenes et al. (1983); Slenes (1985).
} 
que a escravidão "não-plantation" era a regra, e não a exceção, na Minas do início dos oitocentos.

Pode-se indagar da representatividade do quadro traçado por SaintHilaire, com respeito à escravidão brasileira em geral no período. Afinal, ele praticamente não viu cafezais — já que o café apenas começava a expandir-se pelo vale do Paraíba - e, dos vários engenhos de açúcar que menciona, poucos (basicamente, os da região de Campos, no Rio de Janeiro) tinham uma escala de produção característica das regiões de maior produção. Sem ter percorrido regiões onde prevaleceram as duas grandes lavouras escravistas de nossa história econômica, os relatos do Viajante seriam uma amostra viesada do escravismo brasileiro. Sem dúvida, essa é uma questão cuja resposta satisfatória demandará maiores pesquisas.

Por outro lado, é preciso não esquecer que as províncias percorridas por Saint-Hilaire detinham quase a metade do estoque global de escravos do Brasil, na época: de um total de cerca de 1,1 milhão de cativos, estimado para o País em 1819, aproximadamente 487 mil, ou 44\%, estavam nos atuais Estados de Minas Gerais, Rio de Janeiro, Espírito Santo, Goiás, São Paulo,Paraná, Santa Catarina e Rio Grande do Sul (IBGE, 1990:32, Tabela 1.4). Ou seja: o testemunho do Viajante traz consigo a sugestão de que uma parte muito substancial dos escravos brasileiros, no início do século XIX, era, por sua inserção no processo produtivo, de um tipo diferente daquele usualmente considerado o escravo "representativo".

Se os escravos que o Naturalista viu não se dedicavam tipicamente a tarefas intensivas em esforço, então não seria de se esperar que o uso sistemático da coerção e castigos físicos, por parte dos senhores, fosse o método predominante de induzir nos escravos o desempenho desejado. Ao contrário, deveria haver, nesses casos, uma prevalência de incentivos positivos. As opiniões de Saint-Hilaire sobre o caráter suave ou benigno da escravidão brasileira são, assim, coerentes com o que ele observou.

\section{Referências bibliográficas}

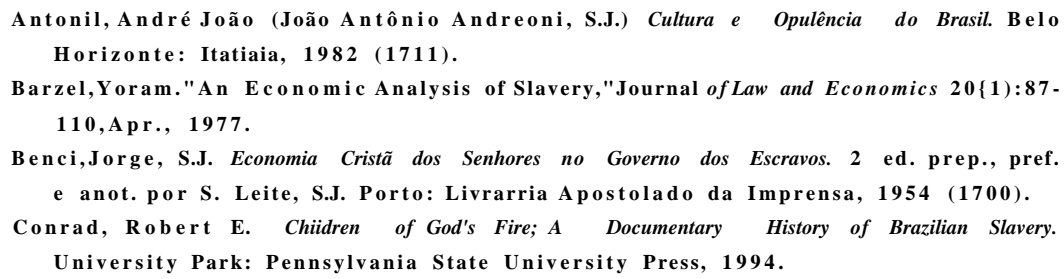


Costa, Emília Viotti da. Da Senzala à Colônia. São Paulo: Difusão Européia do Livro, 1966.

Costa Filho, Miguel. A Cana-de-Açúcar em Minas Gerais. Rio de Janeiro: Insituto do Açúcar e do Álcool, 1963.

Domar, Evsey D. "The Causes of Slavery and Serfdom: a Hypothesis," Journal of Economic History 30(1):18-32, Mar., 1970.

Fenoaltea, Stefano. "Slavery and Supervision in Comparative Perspective: a Model," Journal of Economic History 44(3):635-668, Sept., 1984.

Fogel, RobertW. \& Engerman, Stanley L. Time on lhe Cross. 2 v. Boston: Little, Brown \& Co. 1974.

Freyre, Gilberto. Casa Grande e Senzala; Formação da Família Brasileira sob o Regime da Economia Patriarcal. 21 ed. Rio de Janeiro: José Olympio, 1981 (1933).

Sobrados c Mocambos; Decadência do Patriarcado Rural e Formação do Urbano. 3 ed. Rio de Janeiro: José Olympio, 1961 (1936).

Gorender, Jacob. O Escravismo Colonial. 3 ed. São Paulo: Ática, 1980. . A Escravidão Reabilitada. São Paulo: Ática, 1990.

Hanes, Christopher. "Turnover Cost and the Distributíon of Slave Labor in AngloAmerica."Journal of Economic History 56(2):307-329, Jun., 1996.

Holanda, Sérgio Buarque de. Raízes do Brasil. 5ed.rev. Rio de Janeiro; José Olympio, 1969 (1936).

IBGE - Fundação Instituto Brasileiro de Geografia e Estatística. Estatísticas Históricas do Brasil. 2ed. (Séries Estatísticas Retrospectivas, v. 3). Rio de Janeiro, 1990.

Kahn, Charles."An Agency Approach to Slave Punishments and Awards."Em: Robert W. Fogel \& Stanley Engerman (eds.). Without Consent or Contract; Conditions of Slave Life and The Transition to Freedom. (Technical Papers, v. 2). New York: Norton, 1992.

Karasch, Mary C."From Porterage to Proprietorship: African Occupations in Rio de Janeiro, 1808-1850." In: Engerman, S.L. \& Genovese, E.D. (eds.) Race and Slavery in the Western Hemisphere. Princeton, 1975.

Koster, Henry. Travels in Brazil. London: Longman, Hurst, Rees \& Brown, 1816.

Martins Filho, Amílcar \& Martins, Roberto B. "Slavery in a Nonexport Economy: Nineteenth-Century Minas Gerais Revisited." Hispanic American Historical Review $63(3): 537-568$, A ug., 1983.

. "Reply". Hispanic American Historical Review 64(1): 135-145, Feb., 1984.

Prado Jr., Caio. Formação do Brasil Contemporâneo; Colônia. 17ed. São Paulo: Brasiliense, 1981 (1942).

Saint-Hilaire, Auguste de. Viagem pelo Distrito dos Diamantes e Litoral do Brasil.Ti\&d. L.A.Penna. Belo Horizonte: Itatiaia (Coleção Reconquista do Brasil, v. 5), 1974a (1833).

- Viagem ao Espírito Santo e Rio Doce.Trad. M. Amado. Belo Horizonte: Itatiaia (Coleção Reconquista do Brasil, v. 6), 1974 b (1833).

. Viagem ao Rio Grande do Sul.Trad. L.A.Penna. Belo Horizonte: Itatiaia (Coleção Reconquista do Brasil, v. 10), 1974 c (1887).

Viagem pelas Províncias do Rio de Janeiro e Minas Girais.Trad.V. Moreira. Belo Horizonte: Itatiaia (Coleção Reconquista do Brasil, v. 4), 1975a (1830).

Viagem às Nascentes do Rio São Francisco.Trad. R.R.Junqueira. Belo Horizonte: Itatiaia (Coleção Reconquista do Brasil, v. 7), 1975b (1847). . Viagem à Província de Goiás. Trad. R.R.Junqueira. Belo Horizonte: Itatiaia 
(Coleção Reconquista do Brasil, v. 5), 1975 c (1847).

Segunda Viagem do Rio de Janeiro a Minas Gerais e a São Paulo (1822).Trad.

Moreira. Belo Horizonte: Itatiaia (Coleção Reconquista do Brasil, v. 11), 1975d (1887).

Viagem à Província de São Paulo.Trad. R.R.Junqueira Belo Horizonte: Itatiaia (Coleção Reconquista do Brasil, v. 18), 1976 (1851).

Viagem a Curitiba e Santa Catarina.Trad. R.R.Junqueira. Beío Horizonte: Itatiaia (Coleção Reconquista do Brasil, v. 9), 1978 (1851).

Silva, Marilene R. Nogueira da. Negro na Rua; a Nova Face da Escravidão. São Paulo: Hucitec, 1988 .

Slenes, Robert W. Os Múltiplos de Porcos e Diamantes: A Economia Escrava de Minas Gerais no Século XIX. Campinas: Unicamp,junho. (Cadernos IFCH- Unicamp, $\left.n^{\circ} 17\right), 1985$.

, Dean, W., Stanley L. Engerman \& Genovese, Eugene D. "Commentson Slavery in a Non-Export Economy". Hispanic American Historical Review 63(3): $569-590$, Aug., 1983 .

Versiani, Flávio Rabelo. "Brazilian Slavery: toward an Economic Analysis." Revista Brasileira de Economia 48(4): 463-478, out./dez., 1994. 